\title{
Short Communication: \\ The herpetofauna around human settlements in Lubuklinggau City, South Sumatra, Indonesia: Composition and diversity
}

\author{
DIAN SAMITRA ${ }^{1,2, v}$, ZICO FAKHRUR ROZI ${ }^{1, \bullet v}$ \\ ${ }^{1}$ Biology Education Program, STKIP PGRI Lubuklinggau. Jl. Mayor Toha, Lubuklinggau 31626, South Sumatra, Indonesia. Tel./fax.: +62-733-541432, \\ •email: dian.samitra@gmail.com; •"zico.fakhrurrozi@gmail.com \\ ${ }^{2}$ Zoology Division, Generasi Biologi Indonesia (Genbinesia) Foundation. Jl. Swadaya Barat No.4, Gresik 61171, East Java, Indonesia
}

Manuscript received: 30 December 2019. Revision accepted: 13 March 2020.

\begin{abstract}
Samitra D, Rozi ZF. 2020. Short Communication: The herpetofauna around human settlements in Lubuklinggau City, South Sumatra, Indonesia: Composition and diversity. Biodiversitas 21: 1432-1437. Herpetofauna research has been conducted mostly in conservation forest areas, so little is known about herpetofauna outside the conservation areas, such as those around the human settlements. The data of herpetofauna near human settlements are important in carrying out conservation actions. This study aimed to determine the diversity of herpetofauna around human settlements in the city of Lubuklinggau. The study was conducted from February to August 2019. Herpetofauna samples were taken in three habitats around settlements, i.e., plantation, rice field, and river. Sampling was done with the method of visual encounter survey and time-constrained search. The data were analyzed using ecological indexes, i.e., relative abundance, and indexes of diversity, evenness, similarity, and dominance. The results showed that 378 individuals of herpetofauna were found, belonging to 27 species (12 amphibians and 15 reptiles). Eighteen species were found in the plantation (7 amphibians and 11 reptiles), 15 species in the river (10 amphibians and 5 reptiles), and 14 species in the rice field (6 amphibians and 8 reptiles). Similarity index analysis showed that the rice field had quite different species from other habitats. The herpetofauna diversity around settlements was categorized as medium.
\end{abstract}

Keywords: Amphibians, biodiversity, conservation, reptiles

\section{INTRODUCTION}

Herpetofauna is rarely known and little appreciated by society because of the negative feelings people have toward this animal group (Sousa et al. 2016; Indrawati et al. 2018; Devi et al. 2019). In South and Southeast Asia, herpetofauna research has not received much attention in terms of ecological aspects. Moreover, intensive field surveys are rarely conducted and published (Karthik et al. 2018). Herpetofauna diversity is very important because these animals: (i) play an important role in maintaining the sustainability of ecosystems, (ii) aid human socioeconomics through utilization as tourism objects (Subeno 2018; Riyanto et al. 2019), (iii) act as a pest controller (rat and insect eaters), and (iv) provide germplasm (Subeno 2018; Cahyadi and Arifin 2019).

Herpetofauna, especially amphibians that are very sensitive to environmental changes such as pollution in waters, can be used as an indicator of biodiversity, and local pressure on the environment (Burlibaşa and Gavrilă 2011; Carlsson and Tydén 2018; Priambodo et al. 2019). Herpetofauna has declined in abundance and diversity, and is even threatened with extinction due to rapid urbanization and intensification of agriculture which lead to invasion of alien species and loss of habitat (Carpio et al. 2015; Cassani et al. 2015), and over-exploitation of reptiles and amphibians for consumption, industry, and pet trade (Natusch and Lyons 2012; Shaney et al. 2017).
Rapid urbanization can have an impact on various components of the environment, including land, and is, therefore, a challenge for conservation of biodiversity (Rebelo et al. 2011; Patra et al. 2018). Urbanization replaces natural habitats with infrastructures, such as houses, buildings, roads and other impervious surfaces, which can result in changes in species composition (Vanegas-Guerrero et al. 2016; Hassan and Hassan 2019). However, various studies throughout the world show that some urbanized habitats can maintain substantial biodiversity, including reptiles and amphibians (Montes 2014).

Herpetofauna research has been conducted mostly in conservation areas; therefore, research on the diversity of herpetofauna outside conservation areas, such as those around human settlements, is needed. The herpetofauna data are important as the world population grows and is mostly concentrated in urban areas (Nath et al. 2012). Given the importance of herpetofauna as a bioindicator, data about herpetofauna and changes in habitat conditions will provide herpetofauna information to those involved in carrying out conservation actions (Subeno 2018). No study of herpetofauna diversity in Lubuklinggau, South Sumatra, Indonesia had been conducted previously, so this study was done to determine the diversity of herpetofauna around human settlements in the city of Lubuklinggau. 


\section{MATERIALS AND METHODS}

\section{Study area}

The study was conducted from February to August 2019 in Lubuklinggau city, South Sumatra (Figure 1). Sampling locations consisted of 3 types of habitats, namely a rice field (Figure 2.A), a river (Figure 2.B) and a plantation (Figure 2.C) around human settlements.

\section{Materials}

The materials used for the herpetofauna survey were headlamp, grab-stick, thermo-hygrometer, mercury thermometer, scooping-net, camera, stationery, calipers, specimen pouches, and field guide books to identify, i.e., Iskandar (1998), Kusrini (2013), Inger et al. (2017), and Kamsi et al. (2017).

\section{Data collection}

We used a visual encounter survey (VES) method and a time-limited search technique (Olson et al. 2016; Freitas et al. 2017; Subeno 2018). The search was conducted at 7:0010:00 am and 7:00-10:00 pm West Indonesian Time. Sampling was completed using hands, a scoop-net, or a grab-stick. We recorded the species, number of individuals, the habitat and the time each individual was found. If the samples found were difficult to identify in the field, they were taken to the Biology Education Laboratory at the University of Bengkulu, Indonesia to be identified. Identification was done using the organism's morphology and meristic characters, i.e., body length (SVL), limb tail, length of the head, and diameter of eyes (Subeno 2018; Cahyadi and Arifin 2019). All individuals in the study were released where they were found.

\section{Data analysis}

The data were analyzed to determine the ecological indices, i.e., relative abundance, the Shannon-Wiener diversity index, Pielou evenness index, Jaccard similarity index, and Simpson dominance index (Aguilar-López et al. 2016; Arista et al. 2017; Muslim 2017; Cruz et al. 2019). Analysis and calculations were performed with Microsoft Excel 2007 and MVSP 3.22.

\section{RESULTS AND DISCUSSION}

\section{Species composition}

We discovered 378 individuals and classified them into 27 species, 16 families and 2 orders (Table 1). The amphibians consisted of 12 species belonging to 5 families (Table 2) and the reptiles 15 species belonging 11 families (Table 3 ). The results of the study are similar to the results of other studies conducted in urban areas, forests, and tourist areas. For example, 22 species (11 amphibians and 11 reptiles) of herpetofauna were found in a coal mining area of PT Singlurus Pratama (Muslim et al. 2018). In a national park in West Java, 53 species were found (Cahyadi and Arifin 2019) and 35 species were found in Mount Galunggung (Riyanto et al. 2019).

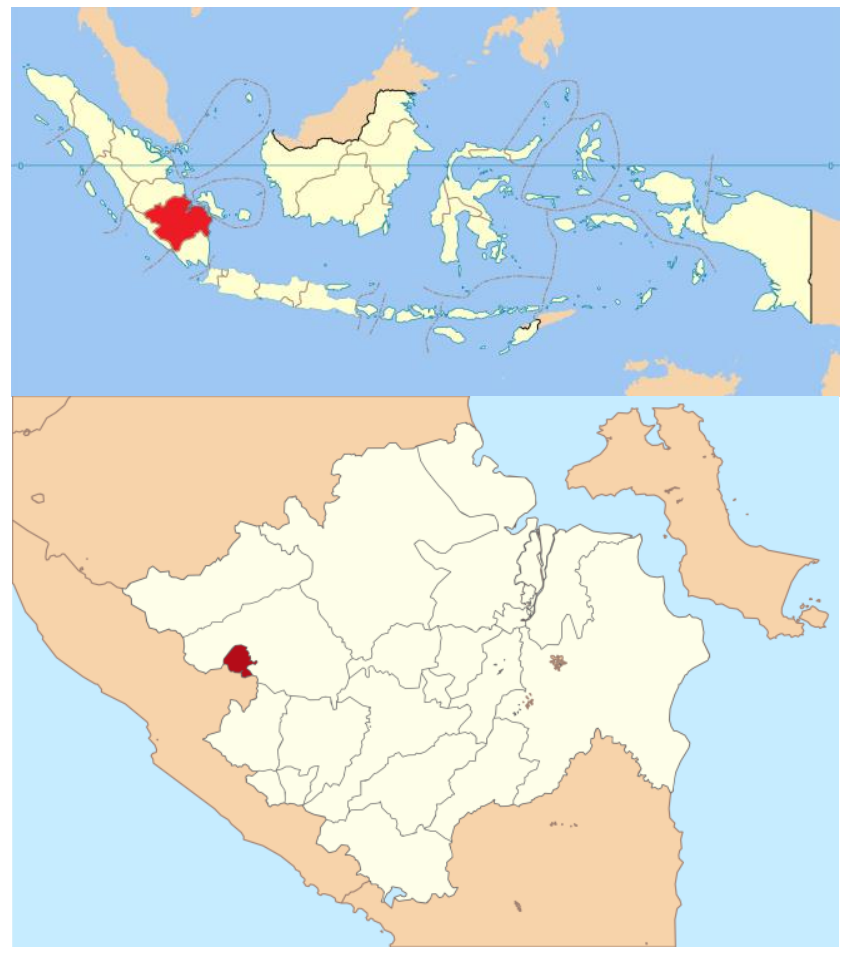

Figure 1. Location of Lubuklinggau City, South Sumatra, Indonesia

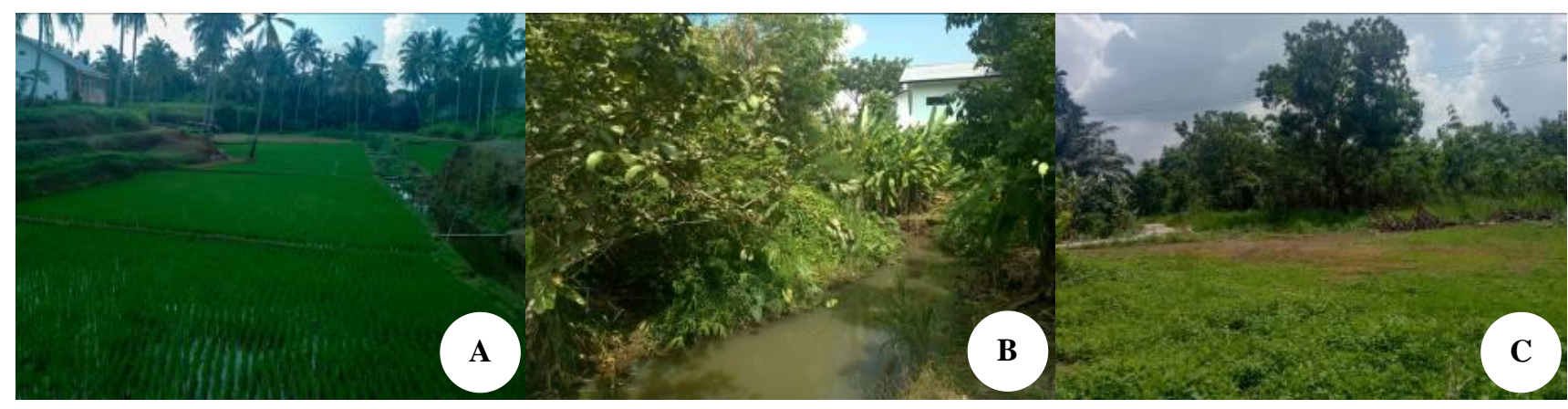

Figure 2. Habitat type around human settlements in Lubuklinggau City, South Sumatra, Indonesia. A Rice field, B. River, C. Community plantation 
The rice field had 14 species belonging to 12 families (Table 1), consisting of 6 species within 4 families of amphibians (Table 2) and 8 species within 8 families of reptiles (Table 3 ). The herpetofauna species observed were common species found in rice fields such as Dutaphyrnus melanotictus, Fajevarya cancrivora, Fajevarya limnocharis, Hylarana erythraea, Takydromus sexlineatus, and Enhydris plumbea (Kamsi et al. 2017; Muslim et al. 2018). Polypedates leucomystax and Bronchocela cristatella were found during the study because shrubs around the rice fields are a habitat for these two species (Kamsi et al. 2017). The finding of Malayphyton reticulatus during the study was unusual because this species is commonly found in primary forests, secondary forests, animal husbandry and settlement areas (Kamsi et al. 2017; IUCN 2019). M. reticulatus was discovered because near the rice field there is a settlement that has animal husbandry. Figure 3 shows the relative abundance of $F$. cancrivora in the rice field was $27 \%$, the highest among the species. Xenopeltis unicolor, M. reticulates, $B$. cristatella, Acrochordus granulatus, and Dendrelaphis pictus had the same low relative abundance, i.e., $0.6 \%$. The number of herpetofauna species found in rice fields in this study was higher than that found in the same habitat in other studies, such as 3 amphibian species in the rice field of Padang Tepong Village (Nopriansyah et al. 2018) and 3 amphibian species in the rice field in Muning Village (Syarif and Maulana 2018), but it was slightly lower than that in the Wonosobo Agricultural Landscape, i.e., 10 amphibians and 5 reptiles (Kurniawan et al. 2016).

In the river, 15 species of herpetofauna belonging to 9 families were found (Table 1), consisting of 10 species within 4 families of amphibians (Table 2) and 5 species within 5 families of reptiles (Table 3). The species most commonly found in the river were $H$. erythraea and $T$. Sexilineatus. H. erythraea was the species with the highest relative abundance in the river, i.e., 20\% (Figure 4), which was expected because, $H$. erythraea usually lives in areas with stagnant waters (Kamsi et al. 2017), such as ponds around rivers. We did not find Varanus salvator in the river, which is its habitat because we only used visual survey. The best sampling technique for $V$. salvator is setting traps. The number of herpetofauna species in the river in Lubuklinggau was relatively higher than that of the same habitat reported in other studies, such as 8 amphibian species in the Opak River (Yudha et al. 2014) and 5 amphibian species around the river in the Bedengan Tourism area of Selorejo Village (Devi et al. 2019), but lower than that in the Code River, i.e., 18 reptile species (Yudha et al. 2016).

Table 1. Number of orders, families and species of herpetofauna around human settlements in Lubuklinggau, South Sumatra, Indonesia

\begin{tabular}{lcccc}
\hline & \multicolumn{3}{c}{ Habitat } & \multirow{2}{*}{ Total } \\
\cline { 2 - 4 } & Rice field & River & Community plantation & \\
\hline Ordo & 2 & 2 & 2 & 2 \\
Family & 12 & 9 & 12 & 16 \\
Species & 14 & 15 & 18 & 27 \\
\hline
\end{tabular}

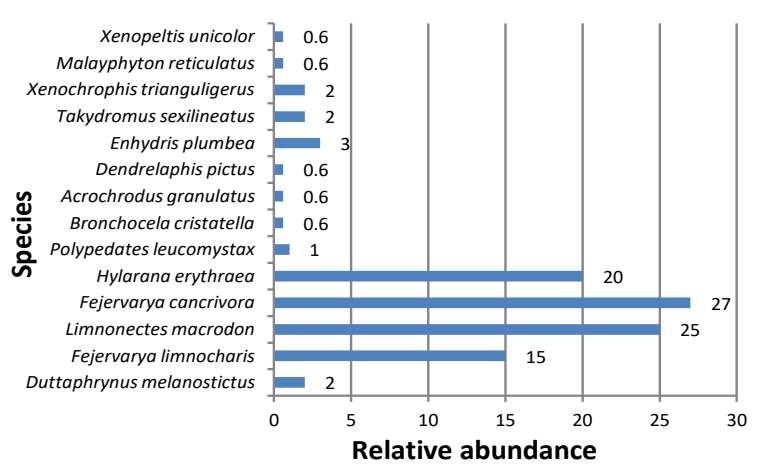

Figure 3. Relative abundance of herpetofauna species in rice field

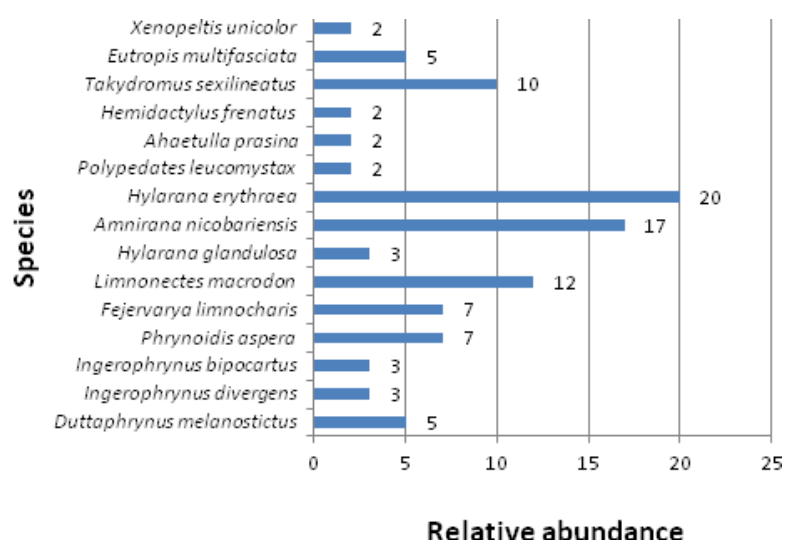

Figure 4. Relative abundance of herpetofauna species in the river

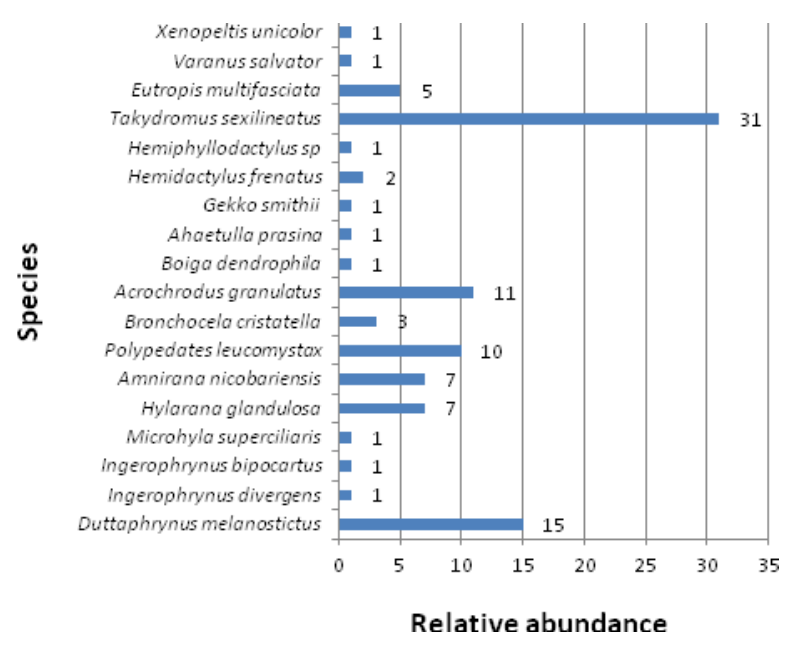

Figure 5. Relative abundance of herpetofauna species in the community plantation 
Table 2. Amphibians around human settlements in Lubuklinggau, South Sumatra, Indonesia

\begin{tabular}{|c|c|c|c|c|}
\hline \multirow[b]{2}{*}{ Family } & \multirow[b]{2}{*}{ Species } & \multicolumn{3}{|c|}{ Habitat } \\
\hline & & لِّ & $\stackrel{\bar{d}}{\ddot{z}}$ & 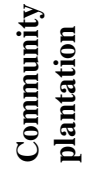 \\
\hline Bufonidae & Duttaphrynus melanostictus & 1 & 1 & 1 \\
\hline Bufonidae & Ingerophrynus divergens & 0 & 1 & 1 \\
\hline Bufonidae & Ingerophrynus biporcatus & 0 & 1 & 1 \\
\hline Bufonidae & Phrynoidis aspera & 0 & 1 & 0 \\
\hline Dicroglossidae & Fejervarya limnocharis & 1 & 1 & 0 \\
\hline Dicroglossidae & Limnonectes macrodon & 1 & 1 & 0 \\
\hline Dicroglossidae & Fejervarya cancrivora & 1 & 0 & 0 \\
\hline Microhylidae & Microhyla superciliaris & 0 & 0 & 1 \\
\hline Ranidae & Hylarana glandulosa & 0 & 1 & 1 \\
\hline Ranidae & Amnirana nicobariensis & 0 & 1 & 1 \\
\hline Ranidae & Hylarana erythraea & 1 & 1 & 0 \\
\hline Rhacophoridae & Polypedates leucomystax & 1 & 1 & 1 \\
\hline
\end{tabular}

Note: 1: presence; 0: absence

Table 3. Reptiles around human settlements in Lubuklinggau, South Sumatra, Indonesia

\begin{tabular}{|c|c|c|c|c|}
\hline \multirow[b]{2}{*}{ Family } & \multirow[b]{2}{*}{ Species } & \multicolumn{3}{|c|}{ Habitat } \\
\hline & & 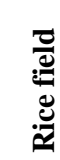 & $\stackrel{\grave{d}}{\Delta}$ & 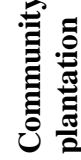 \\
\hline Agamidae & Bronchocela cristatella & 1 & 0 & 1 \\
\hline Acrochordidae & Acrochrodus granulatus & 1 & 0 & 1 \\
\hline Colubridae & Boiga dendrophila & 0 & 0 & 1 \\
\hline Colubridae & Dendrelaphis pictus & 1 & 1 & 0 \\
\hline Colubridae & Ahaetulla prasina & 0 & 0 & 1 \\
\hline Gekkonidae & Gekko smithii & 0 & 0 & 1 \\
\hline Gekkonidae & Hemidactylus frenatus & 0 & 1 & 1 \\
\hline Gekkonidae & Hemiphyllodactylus $\mathrm{sp}$ & 0 & 0 & 1 \\
\hline Homalopsidae . & Enhydris plumbea & 1 & 0 & 0 \\
\hline Lacertidae & Takydromus sexlineatus & 1 & 1 & 1 \\
\hline Natricidae & Xenochrophis trianguligerus & 1 & 0 & 0 \\
\hline Pythonidae & Malayphyton reticulatus & 1 & 0 & 0 \\
\hline Scincidae & Eutropis multifasciata & 0 & 1 & 1 \\
\hline Varanidae & Varanus salvator & 1 & 0 & 1 \\
\hline Xenopeltidae & Xenopeltis unicolor & 0 & 1 & 1 \\
\hline
\end{tabular}

Note: 1: presence; 0: absence

Table 4. Average abiotic data around human settlements in Lubuklinggau, South Sumatra, Indonesia

\begin{tabular}{lccc}
\hline Parameter & \multicolumn{3}{c}{ Habitat } \\
\cline { 2 - 4 } & Rice field & River & $\begin{array}{c}\text { Community } \\
\text { plantation }\end{array}$ \\
\hline Humidity $(\%)$ & 70.8 & 82.5 & 84.1 \\
Air temperature $\left({ }^{\circ} \mathrm{C}\right)$ & 31.9 & 30.5 & 30.9 \\
Water temperature $\left({ }^{\circ} \mathrm{C}\right)$ & 27.1 & 26.2 & 26.8 \\
\hline
\end{tabular}

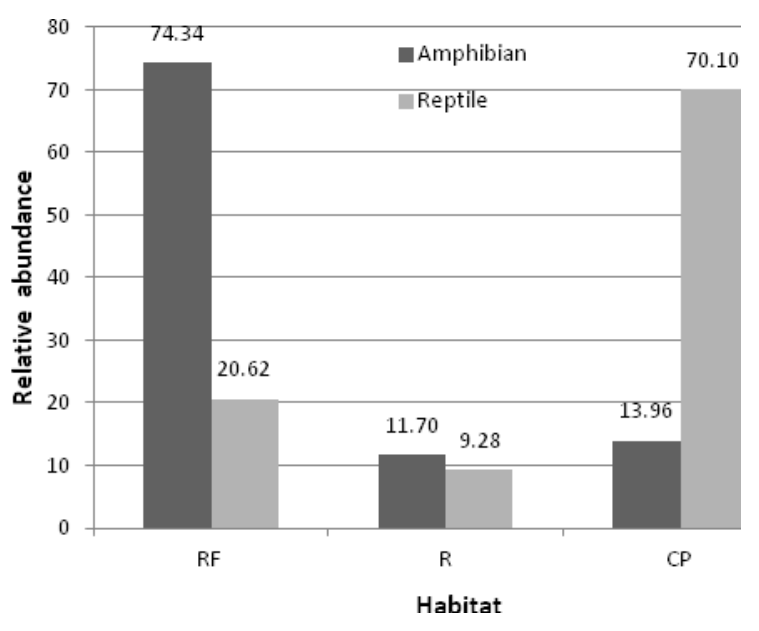

Figure 6. Relative abundance of herpetofauna species by habitat in Lubuklinggau, South Sumatra, Indonesia. RF: rice field; R: river; $\mathrm{CP}$ : community plantation.

In the community plantation, 18 species belonging to 12 families were found (Table 1), consisting of 7 species within 4 families of amphibians (Table 2) and 11 species within 8 families of reptiles (Table 3). The species most commonly found in plantation were Duttaphrynus melanostictus (18 individuals) representing amphibians and T. sexilineatus (45 individuals) representing reptiles. $D$ melanostictus belongs to the family Bufonidae that can be found in areas near settlements including agricultural land (Moore et al. 2015). T. sexlineatus had the highest relative abundance value in the plantation, i.e., 31\% (Figure 5). This finding is not surprising because this species likes areas that have sufficiently thick bushes and grasses (Kamsi et al. 2017). The number of $T$. sexlineatus individuals found in this study was higher than that reported by Kwatrina et al (2019) in the Landscape of oil palm plantation, i.e., 1 individual, presumably because the rubber plantation in Lubuklinggau had grasses, making it an ideal habitat for $T$. sexlineatus.

The number of herpetofauna in the community plantation in this study was relatively higher than that of other studies, such as 7 amphibians and 6 reptiles in the Salak plantation Wonosobo (Kurniawan et al. 2016), 7 amphibians and 7 reptiles in PT ASMR's oil palm plantation, Central Borneo (Santosa and Rejeki 2019) and 9 amphibians and 8 reptiles in the oil palm plantation of PT. Central Borneo BLP (Kwartina et al. 2018).

The relative abundance based on habitat (Figure 6) shows that rice field had the largest number of amphibians $(70.34 \%)$ and the plantation had the largest number of reptiles $(70.10 \%)$. The difference in abundance and number of herpetofauna species is due to environmental conditions, i.e., vegetation types, water quality, humidity, and temperature (Kurniawan et al. 2016; Subeno 2018). The temperature and humidity at the study site (Table 4) were still in the range for the life of herpetofauna, i.e., $20-40^{\circ} \mathrm{C}$ and $40-100 \%$ respectively (Khartik et al. 2018; Septiadi et al. 2018). 
Table 5. Ecological indices of herpetofauna around human settlements in Lubuklinggau, South Sumatra, Indonesia

\begin{tabular}{lccc}
\hline Habitat & $\begin{array}{c}\text { Diversity } \\
\text { index }\end{array}$ & $\begin{array}{c}\text { Evenness } \\
\text { index }\end{array}$ & $\begin{array}{c}\text { Dominance } \\
\text { index }\end{array}$ \\
\hline Rice field & 1.82 & 0.69 & 0.20 \\
River & 2.41 & 0.89 & 0.11 \\
Community plantation & 2.20 & 0.76 & 0.16 \\
Overall & 2.55 & 0.77 & 0.10 \\
\hline
\end{tabular}

Table 6. Jaccard similarity index of herpetofauna around human settlements in Lubuklinggau, South Sumatra, Indonesia

\begin{tabular}{lccc}
\hline Habitat & $\begin{array}{c}\text { Diversity } \\
\text { index }\end{array}$ & $\begin{array}{c}\text { Evenness } \\
\text { index }\end{array}$ & $\begin{array}{c}\text { Dominance } \\
\text { index }\end{array}$ \\
\hline Rice field & - & - & - \\
River & 0.32 & - & - \\
Community plantation & 0.23 & 0.43 & - \\
\hline
\end{tabular}

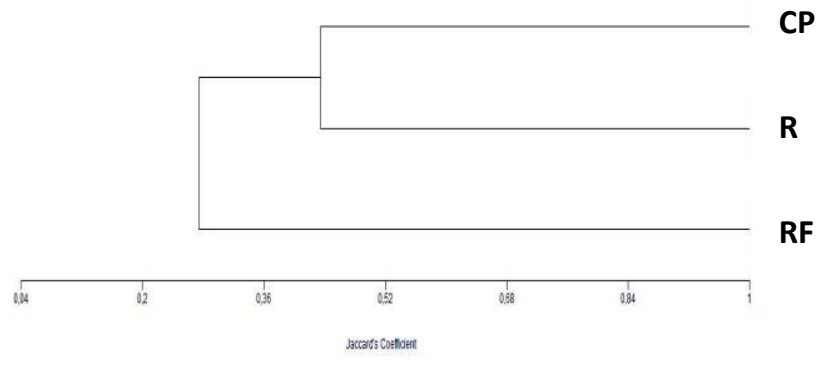

Figure 7. Dendrogram of similarity in three habitats, using MVSP 3.22. CP: Community plantation; R: river: RF: rice field

\section{Ecological indices}

Overall, the diversity index is categorized as medium, the evenness index high, and the dominance index low (Table 5). This indicates that the habitat around community settlements is still good for herpetofauna. The presence of water, bushes, litter, and lush trees around the settlements make an ideal place for herpetofauna to live. The moist microhabitat, due to the tight canopy cover and lots of litter, becomes an influential factor on herpetofauna especially for amphibians (Wanger et al. 2011; Qurniawan 2015; Kwatrina et al. 2019).

The value of diversity index in the rice field (1.82) was lower than that of the river (2.41) and plantation (2.20), which means that the river and plantation diversity was medium, while that of the rice field was low. The difference in diversity index values between habitat types is caused by humidity (Dutta and Mukhopadhyay 2013). This is proven by the fact that rice field had lower humidity (Table 4). Evenness Index is important because it can assess the abundance of each species in a community that is evenly distributed (Dutta and Mukhopadhyay 2013; Chatterjee and Mondal 2016). The Evenness Index in the rice field (0.69), was lower than that in the river (0.89) and plantation (0.76). These findings may be interpreted that the herpetofauna species in the river and plantation were more evenly distributed than in the rice field.

The dominance index in the rice field was higher than that of other habitats (Table 5) because several species from the rice field had relatively high abundance (Figure 3 ), indicating that rice field is the ideal habitat for these three species (Kamsi et al. 2017). Homogeneous microhabitats such as in the rice field reduce the number of niches which lead to the low diversity of herpetofauna (Muslim et al. 2018). In addition, without litter and lack of tree canopy cover, the rice field has low relative humidity and high fluctuation of temperature between night and day, which cause herpetofauna diversity to decrease (Gillespie et al. 2015; Saccol et al. 2017; Kwatrina et al. 2019).

Species similarity for among habitats was calculated using the Jaccard index (Table 6) and analyzed using MVSP 3.22. (Figure 7). The rice field habitat was separated because the number of common species was less when compared to the river and plantation habitats. The river and plantation habitats had higher common species (10 species) because there were shrubs, trees, and litter around the river.

\section{ACKNOWLEDGEMENTS}

We would like to thank Feri Setiawan, Dwi Novita Syari Harahap, Meilianysah, Nugroho Aji Waluyo and the Herpetofauna Lubuklinggau Team for helping us gather data. Special thanks to Dr. Patricia G. Patrick (Columbus State University, USA) for useful discussions.

\section{REFERENCES}

Arista A, Winarno GD, Hilmanto R. 2017. Keanekaragaman jenis amfibi untuk mendukung kegiatan ekowisata di Desa Braja Harjosari Kabupaten Lampung Timur. Biosfera 34 (3): 103-109. DOI: 10.20884/1.mib.2017.34.3.458. [Indonesian]

Aguilar-López JL, Eduardo P, Luría-Manzano R, Canseco-Márquez L. 2016. Species diversity, distribution, and conservation status in a Mesoamerican region: Amphibians of the Uxpanapa-Chimalapas region, Mexico. Trop Conserv Sci 9 (4): 1-16. DOI: 10.1177/1940082916670003.

Burlibașa L, Gavrilă L. 2011. Amphibians as model organisms for study environmental genotoxicity. Appl Ecol Environ Res 9 (1): 1-15.

Cahyadi G, Arifin U. 2019. Potential and challenges on amphibians and reptiles research in West Java. Jurnal Biodjati 4 (2): 149-162. DOI: 10.15575/biodjati.v4i2.4820.

Carlsson G, Tydén E. 2018. Development and evaluation of gene expression biomarkers for chemical pollution in common frog (Rana temporaria) tadpoles. Environ Sci Pollut Res 25: 33131-33139.

Carpio AJ, Cabrera M, Tortosa FS. 2015. Evaluation of methods for estimating species richness and abundance of reptiles in olive groves. Herpetol Conserv Biol 10 (1): 54-63.

Cassani JR, Croshaw DA, Bozzo J, et al. 2015. Herpetofauna community change in multiple habitats after fifteen years in a Southwest Florida Preserve, USA. PLoS ONE 10 (5): e0125845. DOI:10.1371/journal.pone.012584.

Chatterjee P, Mondal K. 2016. Diversity of Anurans and their habitat preference in temporary water pools of a rock mining area at Steel City Durgapur, East India. Adv Biol Res 10 (6): 374-381.

Cruz PHPG, Afuang LE, Gonzalez JCT, Gruezo WSM. 2019. Distribution and diversity patterns of herpetofauna in the Pantabangan-Carranglan 
Watershed, Nueva Ecija, Caraballo Mountain Range, Philippines. Biodivers Data J 7: e31638. 1:23 DOI: 10.3897/BDJ.7.e31638.

Devi SR, Septiadi L, Erfanda MP et al. 2019. Struktur komunitas ordo anura di lokasi Wisata Bedengan, Desa Selorejo, Kecamatan Dau, Kabupaten Malang. Jurnal Riset Biologi dan Aplikasinya 1 (2): 71 79. [Indonesian]

Dutta S, Mukhopadhyay SK. 2013. Habitat preference and diversity of anuran in Durgapur, an industrial city of West Bengal, India. Proc Zool Soc 66 (1): 36-40.

Freitas MA, Vieira RS, Entiauspe-Neto OM et al. 2017. Herpetofauna of the Northwest Amazon forest in the state of Maranhão, Brazil, with remarks on the Gurupi Biological Reserve. ZooKeys 643: 141-155. DOI:10.3897/zookeys.643.8215.

Gillespie GR, Howard S, Stroud JT et al. 2015. Responses of tropical forest herpetofauna to moderate anthropogenic disturbance and effects of natural habitat variation in Sulawesi, Indonesia. Bio Conserv 192: 161-173. DOI: 10.1016/j.biocon.2015.08.034

Hassan MO, Hassan YM. 2019. Effect of human activities on floristic composition and diversity of desert and urban vegetation in a new urbanized desert ecosystem. Heliyon 5: 1-10.

Indrawati Y, Hanifa BF, Septiadi L, Alwi MZ, Khatimah A, Azizah I 2018. Keanekaragaman Jenis Herpetofauna Nokturnal di Area Coban Jahe, Desa Pandansari Lor, Kecamatan Tumpang, Kabupaten Malang, Jawa Timur. Prosiding Seminar Nasional VI Hayati 2018 [Indonesian]

Inger RF, Stuebing RB, Grafe UT, Dehling JM. 2017. A Field Guide of The Frogs of Borneo. Natural History Publication (Borneo). Kota Kinabalu

Iskandar DT. 1998. Amfibi Jawa dan Bali. Puslitbang Biologi-LIPI, Bogor. [Indonesian]

IUCN. 2019. The IUCN Red List of Threatened Species. Version 2019-3. http://www.iucnredlist.org.

Kamsi M, Handayani S, Siregar AJ, Fredriksson G. 2017. Buku Panduan Lapangan Amfibi Reptil Kawasan Hutan Batang Toru. Herpetologe Mania Publishing, Medan. [Indonesian]

Karthik P, Kalaimani A, Nagarajan R. 2018. An inventory on herpetofauna with emphasis on conservation from Gingee Hills, Eastern-Ghats, Southern India. Asian J Conserv Biol 7 (1): 2-16

Kurniawan N, Yanuwiadi B, Priambodo B et al. 2016. Various vegetation modifies the diversity of herpetofauna in Wonosobo agricultura landscape. J Environ Eng Sustain Technol 04 (02): 138-142. DOI:10.21776/ub.jeest.2017.004.02.10

Kusrini MD. 2013. Panduan Bergambar Identifikasi Amfibi Jawa Barat. Fakultas Kehutanan IPB dan Direktorat Konservasi Keanekaragaman Hayati, Bogor. [Indonesian]

Kwartina RT, Santosa Y, Bismark M, Santoso N. 2018. The impact of oil palm plantation estabilishment on the habitat species diversity, and feeding gulid of mammals and herpetofauna. Biodiversitas 19 (4): 1213-1219. DOI: $10.13057 /$ biodiv/d190405.

Kwatrina RT, Santosa Y, Maulana P. 2019. Keanekaragaman spesies herpetofauna pada berbagai tipe tutupan lahan di lansekap perkebunan sawit: Studi Kasus di PT. BLP Central Borneo. Jurnal Pengelolaan Sumberdaya Alam dan Lingkungan 9 (2): 304-313. DOI: 10.29244/jps1.9.2.304-313. [Indonesian]

Montes A H. 2014. Maintaining Herpetofaunal Diversity in Urban Landscape: Implications for Conservation. [Thesis]. University of Puerto Rico Rio Piedras Campus, Puerto Rico.

Moore M, Fidy JFSN, Edmonds D. 2015. The new toad in town: Distribution of the Asian toad, Duttaphrynus melanostictus, in the Toamasina area of eastern Madagascar. Trop Conserv Sci 8 (2): 440455. DOI: $10.1177 / 194008291500800210$.

Muslim T. 2017 Herpetofauna community establishment on the microhabitat as a result of land mines fragmentation in Eas Kalimantan, Indonesia. Biodiversitas 18 (2): 709-714. DOI: 10.13057/biodiv/d180238.

Muslim T, Rayadin Y, Suhardiman A. 2018. Preferensi habitat berdasarkan distribusi spasial herpetofauna di kawasan pertambangan batubara PT Singlurus Pratama, Kalimantan Timur. Jurnal Agrifor XVII (1): 175-190. DOI: 10.31293/af.v17i1.3361. [Indonesian]

Nath A, Sutradhar S, Man AK et al. 2012. Herpetofaunal assemblage with special emphasis on community structure and spatiality in amphibians of Cauvery delta region, Tamil Nadu. Asian J Conserv Biol 1 (2): 7885

Natusch DJD, Lyons JA. 2012. Exploited for pets: the harvest and trade of amphibians and reptiles from Indonesian New Guinea. Biodivers Conserv 21 (11): 2899-2911. DOI: 10.1007/s10531-012-0345-8.

Nopriansyah R, Kasmiruddin, Suryani SD. 2018. Jenis-jenis anura yang terdapat di Kawasan Desa Padang Tepong Kecamatan Ulumusi Kabupaten Empat Lawang. Prosiding Seminar Nasional Pendidikan Biologi, Mataram, 30 September 2017. [Indonesian]

Olson EO, Shedd JD, Engstrom TN. 2016. A field inventory and collections summary of herpetofauna from the Sutter Buttes, an " Inland Island " within California's Great Central Valley. West N Am Nat 76 (3): 352-366 DOI: 10.3398/064.076.0311.

Patra S, Sahoo S, Mishra P, Mahapatra SM. 2018. Impacts of urbanization on land use/cover changes and its probable implications on local climate and groundwater level. J Urban Manag 7 (2): 70-84. DOI:10.1016/j.jum.2018.04.006

Priambodo B, Permana H, Akhsani F. 2019. Characteristics of water sources in Malang, based on the diversity, community structure, and the role of herpetofauna as bioindicators. EurAsian J BioSci 13: 22792283.

Qurniawan TF. 2015. Model of microclimatic influence on fluctuation of herpetofauna diversity in campus area. Jurnal Teknosains 4 (2): 172178. DOI: 10.22146/teknosains.7971. [Indonesian]

Rebelo AG, Holmes PM, Dorse C, Wood J. 2011. Impacts of urbanization in a biodiversity hotspot: Conservation challenges in Metropolitan Cape Town. South Afr J Bot 77: 20-35.

Riyanto A, Sulaeman TN, Rachman N et al. 2019. Herpetofauna diversity, potential ecotourism in Mount Galunggung, West Java, Indonesia. Biodiversitas 20 (4): 1173-1179. DOI: 10.13057/biodiv/d200433.

Saccol SSA, Bolzan AMR, Santos TG. 2017. In the shadow of trees: Does eucalyptus afforestation reduce herpetofaunal diversity in Southern Brazil. South Am J Herpetol 12 (1): 42-56. DOI: 10.2994/sajh-d-1600028.1 .

Santosa Y, Rejeki SSS. 2019. Variation of herpetofauna in different land cover types PT ASMR oil palm plantation, Central Kalimantan Province. AIP Conference Proceedings 2019. DOI: 10.1063/1.5061912.

Septiadi L, Hanifa, BF Khatimah A, Indawati Y, Alwi MZ. 2018. Study of reptile and amphibian diversity at Ledok Amprong Poncokusumo, Malang East Java. Jurnal Biotropika 6 (2): 45-53.

Shaney KJ, Wostl E, Hamidy A et al. 2017. Conservation challenges regarding species status assessments in biogeographically complex regions: examples from overexploited reptiles of Indonesia. Oryx 51 (4): 627-638. DOI:10.1017/S0030605316000351.

Sousa E, Quintino V, Palhas J, Rodrigues AM, Teixeira J. 2016. Can environmental education actions change public attitudes? an example using the pond habitat and associated biodiversity. PLOS ONE 11 (5): e0154440. DOI: 10.1371/journal.pone.0154440.

Subeno. 2018. Distribusi dan keanekaragaman herpetofauna di hulu sungai Gunung Sindoro, Jawa Tengah. Jurnal Ilmu Kehutanan 12: 4051 DOI:10.22146/jik.34108. [Indonesian]

Syarif MA, Maulana F. 2018. Keanekaragaman jenis dan kemelimpahan amfibi di Desa Muning dalam Kecamatan Daha Selatan Kabupaten Hulu Sungai Selatan. Jurnal Pendidikan Hayati 4 (4): 195 - 200. [Indonesian]

Vanegas-Guerrero J, Fernández C, Buitrago-González W. 2016. Urban remnant forests : are they important for herpetofaunal conservation in Urban Remnant Forests: Are they important for herpetofaunal conservation in the Central Andes of Colombia? Herpetol Rev 47 (2): 180-185.

Wanger TC, Motzke I, Saleh S, Iskandar DT. 2011. The amphibians and reptiles of the Lore Lindu National Park area, Central Sulawesi, Indonesia. Salamandra 47 (1): 17-29.

Yudha DS, Eprilurahman R, Trijoko et al. 2014. Keanekaragaman jenis katak dan kodok (Ordo Anura) di sepanjang Sungai Opak Propinsi Daerah Istimewa Yogyakarta. Jurnal Biologi 18 (2): 52 - 59. [Indonesian]

Yudha DS, Eprilurahman R, Jayanto H, Wiryawan IF. 2016. Keanekaragaman jenis kadal dan ular (Squamata: Reptilia) di sepanjang Sungai Code, Daerah Istimewa Yogyakarta. Biota 1 (1): 31-38. [Indonesian] 